\title{
KIRJOITUS
}

ISTO PELTOMÄKI

\section{Kärsimys ja rakkaus. Cura animarum mundana}

"Kärsimykset viitoittavat tietä aikaan, jolloin kärsimyksiä ei ole" "Henkiselle kärsimykselle on vain yksi vastalääke, ja se on ruumiillinen tuska" "Koko elämä on kärsimystä"

"Kärsi, kärsi, kirkkaamman kruunun saat"

"Jumala on minua kuin koiraa koko elämäni rautaruoskalla lyönyt, ja se on ollut minulle tarpeellista”

"Yksi jos murtuis, muut tukena ois"

Kärsimys on väistämätön osa elämää. Jokainen maailmankatsomus, filosofinen suuntaus ja uskonto sisältää selityksen kärsimykselle. Kärsimystä ovat pohtineet monet filosofit ja teologit, kärsimykselle on muotoutunut kansan suussa selityksiä, kuten edellä siteeratuista lauseistakin käy ilmi.

On polttava eettinen kysymys, miten kärsimystä pyritään lievittämään: miten läheisen hätään vastataan, miten ihmisen henkinen hätä kohdataan. Tavat lievittää kärsimystä muotoutuvat sen varassa, minkälainen selitys kärsimykselle annetaan - mistä kärsimys oikeastaan johtuu, miten se tulisi kohdata ja miten siitä voisi vapautua. Siksi kärsimystä koskevat selitykset ovat tärkeitä.

Miten kärsimystä pyritään lievittämään Suomen evankelis-luterilaisessa kirkossa? Minkälaisen kärsimystä koskevan selityksen varassa ihmisen hätä kohdataan kirkon pastoraalisessa työssä? Miten tämä on muuttunut kirkon historian aikana? Erityisen kiinnostavaa on, mitä kirkko opettaa siitä, millä tavoin sen jäseninä olevien kristittyjen tulee lievittää läheistensä kärsimystä. 
Lisäksi on kysyttävä, miten kärsimystä tulisi moraalin kannalta lievittää. Millaisen kärsimystä koskevan selityksen varaan kärsimyksen lievittäminen tulisi rakentaa?

Kirkon edustamaa kärsimystä koskevaa käsitystä ja sen historiallista muutosta voi tarkastella epäsuorasti tutkimalla sielunhoitoa. Sielunhoito on nimenomaan kristillistä henkistä auttamista - siis kärsivän ihmisen kohtaamista ja kärsimyksen lievittämistä.

Sielunhoidon kautta voi tutkia myös sitä, mitä kirkko opettaa kaikkien kristittyjen tehtävästä lievittää kärsimystä. Kirkon opetuksen mukaan sielunhoito on kaikkien sen jäseninä olevien kristittyjen ja seurakuntalaisten tehtävä. Tämä on sanottu kirkkolaissa ja kirkkojärjestyksessä asti, mutta siihen on kiinnitetty niin tutkimuksessa kuin kirkossa vain vähän huomiota.

\section{Sielunhoito kaikkien kristittyjen tehtävänä}

Opetus sielunhoidon kuulumisesta kaikkien kristittyjen tehtäväksi perustuu Martin Lutherin teologiaan ja siitä tehtyyn tulkintaan, varsinkin niin sanottuun yleiseen pappeuteen. Yleinen pappeus tarkoittaa sitä, että on kaikkien kristittyjen tehtävä julistaa ja edistää evankeliumia eikä ainoastaan papiksi nimenomaisesti vihittyjen tehtävä. Sielunhoidon kuuluminen kaikkien kristittyjen tehtäväksi on edelleen perusteltu Lutherin evankeliumin toteutumisen jaottelun perusteella. Luther luetteli - ihan peruskäsityksiä toistaen -, että evankeliumi toteutuu saarnan välityksellä, kasteessa, ehtoollisessa ja ripissä, mutta myös kristittyjen keskinäisessä keskustelussa ja lohdutuksessa.

Evankeliumi siis toteutuu ja tulee edistetyksi siinä, että kristitty pyrkii keskustelussa tarjoamaan apua kärsivälle läheiselleen. Luterilaisen opetuksen mukaan kristityt siis toimivat ainakin lähtökohtaisesti sielunhoitajina arkisessa elämässään pyrkiessään tarjota apua kärsiville läheisilleen.

Ei ole kuitenkaan tarkalleen selvää, millä perusteilla kirkon jäsenien voi sanoa toimivan sielunhoitajina. Sielunhoito on kärsimyksen lievittämisenä moraalista toimintaa ja kristilliseen uskoon kytkeytyvänä myös uskonnollista toimintaa. Minkä ehtojen on täytyttävä, jotta henkinen apu olisi uskonnollista ja siten sielunhoitoa?

Lutherin vastaus oli selvä: kristittyjen keskinäisessä keskustelussa on julistettava evankeliumia ja ohjattava rukoukseen. Olisi tietysti helppo ja yksioikoinen ratkaisu edellyttää myös nykypäivän kristityiltä samaa, jotta heidän 
voisi sanoa toimivan sielunhoitajina. Onko nykypäivän suomalaisilta kirkon jäseniltä kuitenkaan mielekästä odottaa ja edellyttää, että he lohduttaisivat läheisiään puhumalla evankeliumista ja yhdessä rukoilemalla?

Kysymys koskettaa sitä, miten kirkon kokonaistehtävän toteuttaminen perustellaan ja sitä, mitä odotuksia kristittynä olemiselle asetetaan. Nykyistä kirkkoa määrittävä, toisen maailmansodan jälkeen muotoiltu kansankirkkoajattelu perustuu ensinnä sille, että kristittynä olemiselle ei aseteta kriteerejä, joiden täyttämistä kirkkokurin keinoin valvottaisiin. Tällä perusteella kirkko pyrkii palvelemaan koko kansaa eikä ainoastaan jonkinlaista tosiuskovien yhteisöä. Toiseksi kansankirkossa uskonnollista tehtävää julistaa evankeliumia toteutetaan uskonnollisen toiminnan ohella sosiaalisessa työssä, kuten lapsija nuoristyössä ja diakoniassa. Tällaista kirkon teologista itseymmärrystä voi kutsua sosiaalisesti orientoituneeksi luterilaisuudeksi.

\section{Terapeuttinen käänne}

Kirkon nykyinen sielunhoito kytkeytyy sosiaalisesti orientoituneeseen luterilaisuuteen, jonka myötä sielunhoito muuttui radikaalisti 1960-luvulta lähtien. Vielä 1900-luvun alkupuolella sielunhoito oli leimallisesti uskonnollisesti orientoitunutta. Papin tehtävä oli saarnata evankeliumia, lukea lohduttavia raamatunjakeita ja ohjata oikeanlaiseen kristilliseen elämään. Näin myös vastaus kärsimykseen oli uskonnollinen; hädässä olevaa pyrittiin ohjaamaan Jumalan tuntemukseen tavalla tai toisella. Historiallisesti keskeistä on ollut myös kirkkokuri eli oikeanlaisen käyttäytymisen sekä uskonnollisen ajattelun ja toiminnan valvonta ja mahdollinen rankaisu.

Uskonnollisesti orientoitunut sielunhoidon malli ei ole mahdollinen nykypäivän suomalaisessa yhteiskunnassa. Se johtuu siitä, että maallistumisprosessin myötä lumous on purkautunut. Ennen modernia aikaa maailma ymmärrettiin - laveasti kuvaten - niin sanotusti lumottuna. Aistit ylittävää transsendenttia todellisuutta ja Jumalan olemassaoloa pidettiin itsestään selvästi tosina. Tällaisen maailmankuvan puitteissa tiukasti uskonnollisella auttamisella lienee ollut myös terapeuttinen, ihmistä henkisesti auttava vaikutus.

Maallistumisen ja lumouksen purkautumisen myötä uskonnollisesti orientoitunut sielunhoito on menettänyt selitysvoimansa. Uusi, nykyaikainen sielunhoidon auttamisen tapa rakentui reaktiona aatehistorialliseen kehitykseen. Irja Kilpeläisen 1960-luvulla muotoilemasta lähimmäiskeskeisestä sie- 
lunhoidon metodista tuli malli, jonka mukaan kirkon hengellisen työn tekijät edelleen koulutetaan kohtaamaan kärsimystä. Perusideana on, että ihmisen kärsimys kohdataan sellaisena kuin kärsivä ihminen sen itse ymmärtää ja siitä kertoo. Sielunhoitajan tehtävänä on kuunnella, pyrkiä ymmärtämään ja osoittaa myötätuntoa. Pappeja on siis 1960-luvulta lähtien koulutettu olemaan hiljaa; olemaan hiljaa kärsivän ihmisen edessä - eikä se ole helppo tehtävä, helpompaa olisi saada saarnata valmis vastaus. Näin on tapahtunut käänne terapeuttiseen lähestymistapaan. Käänteeseen kuuluu myös kirkkokurista luopuminen, missä ilmenee luopuminen kristillisyydestä, joka perustuu ajatukseen kristittynä olemisen ihanteen täyttämisestä.

Sisällyttävätkö kirkon jäseninä olevat kristityt, siis tavalliset suomalaiset luterilaiset, uskonnollisia merkityksiä lähimmäisten tukemiseen ja auttamiseen? Tutkimusta varten haastateltu pieni kirkon jäseninä olevien kristittyjen otanta ilmentää sellaista uskonnollisuutta, jota ei ole mielekästä tarkastella luterilaisen opillisen uskontulkinnan noudattamisena. Sen sijaan suomalaista luterilaista uskonnollisuutta ja sielunhoitoa osana uskonnollista toimintaa on tutkittava elettynä eli siitä näkökulmasta, että uskonnollisuus on toimintaa, tapoja ja uskomuksia, jotka eivät ole opin ja opetuksen noudattamista.

Kukaan haastatelluista ei kertonut sellaista, että hän sisällyttäisi arkiseen lähimmäistensä tukemiseen uskonnollisia merkityksiä. Suomalaista uskonnollisuutta koskevat tutkimukset tukevat tulkintaa, että tämä haastattelujen tulos koskee suurinta osaa kirkon jäsenistä. Lutherin olettamusta, että kristityt julistavat hädässä olevalle läheiselle evankeliumia, ei voi pitää mahdollisena tämän päivän maallistuneessa suomalaisessa yhteiskunnassa. Uskonnollisuuden tarkasteleminen elettynä perustuu myös näkökohtaan, että uskonnollisuus on luonteeltaan kontekstuaalista; uskonnollisuuden tarkastelussa on otettava huomioon aatehistoria, jonka puitteissa ihmiset ilmentävät uskonnollisuuttaan.

\section{Kärsimyksen lievittäminen on rakkautta}

Sielunhoitoa on tarkasteltava moraalisena toimintana. Mielekäs lähtökohta on tutkia kärsimyksen lievittämistä rakkautena. Rakkauden näkökulma sisältää myös sielunhoidon uskonnollisen ulottuvuuden, koska kristillisyydessä Jumala kuvataan täydellisenä rakkautena. Tarkasteltaessa rakkautta moraalisena toimintana kysymyksenä on, miten edistetään lähimmäisen hyvää. Lutherin 
rakkauden malli taas oli luonteeltaan uskonnollinen. Kysymyksenä ei niinkään ollut lähimmäiselle hyvän tekemisen ja sen ehtojen tarkasteleminen, vaan ihmisen jumalauskon ehtojen tutkiminen, koska Lutherille todellisen rakkauden ainoana kriteerinä oli vain uskon kautta tapahtuva Jumalan tahdon toteuttaminen. Tällaisesta etiikan muotoilusta on kuitenkin luovuttu kirkossa 1900-luvun lopulla, kun moraalia on ryhdytty perustelemaan lähimmäisen hyvän toteuttamisena.

Lähtökohtana kärsimyksen lievittämisen tutkimisessa rakkautena on, että kärsimys, toisten ihmisten kärsimys on otettava vakavasti. Kärsimys ei ole filosofille teoreettinen kysymys, vaan aktuaalinen ihmisiä koskettava ongelma. Kärsimyksen todellisuus on ylipäätään etiikan lähtökohta. Moraalista tarkastelua tarvitaan, koska maailmassa on pahaa. Kärsimys on sekä konkreettisesti että käsitteellisesti ihmiselle koituvaa ja ihmisen kokemaa pahaa. Kärsimys on itse elämän, kaiken hyvän estymistä. Eikä ole triviaalia, millaisia muotoja kärsimys saa, koska se kertoo aikamme kärsimystä tuottavista rakenteista.

Traditionaalinen kristillinen rakkauden malli on perustunut itsensä uhraavan antamisen idealle. Korkein inhimillinen rakkaus, agape, imitoi jumalallista ehdottoman epäitsekästä kaiken antamista. Tällainen moraalisen toiminnan ihanne on kuitenkin hylättävä. Se johtuu perimmältään siitä, että ihminen on paitsi saaja myös antaja suhteessa toisiin. Suhteessa Jumalaan ihminen on vain vastaanottaja, mutta moraalisessa toiminnassa ihmisen hyvä ei toteudu ainoastaan vastaanottajan roolissa. Siksi rakkauden on rakennuttava vastavuoroisuuden varaan.

Vastavuoroisuus voi toteutua vain, kun rakkauden osoittaja, hyvän antaja tai tekijä kunnioittaa toimintansa kohdetta itsensä veroisena toimijana ja mahdollisena antajana. Vastavuoroisuuden idean varaan rakentuva rakkaus on luonteeltaan kunnioittamiseen ja toisen ihmisen tunnustamiseen perustuvaa rakkautta. Vastavuoroisuuden vaade johtuu ihmisen intersubjektiivisesta perusluonteesta. Ihminen on yksilöllinen itsensä, oma persoonansa vain niiden sosiaalisten suhteiden kautta, joissa tämä tulee tunnustetuksi, ja ihminen voi kasvaa persoonaksi vain, kun on ihmisiä, jotka ottavat tämän vastaan ja osoittavat rakkautta ja huolenpitoa. Siksi länsimaisen valistuksen kartesiolainen solipsistinen filosofian metodi tai lähtökohta on hylättävä: moraalisen toiminnan tutkimuksen lähtökohtana ei ole yksilön tietämisen rajat, vaan ihminen intersubjektiivisena, sosiaalisten suhteiden kautta yksilöksi ja persoonaksi muodostuvana ja olevana olentona. 


\section{Kärsimys on mieletöntä}

Kärsimys on ihmiselle koituvaa pahaa. Kärsimys ja paha haastavat ja kyseenalaistavat elämän merkityksellisyyden ja mielekkyyden. Kysymys kärsimyksen ja pahan tarkoituksesta on filosofinen ja myös uskonnollinen. Kristillisessä opetuksessa kärsimys on selitetty syntiinlankeemuksesta johtuvana ja suhteessa Jumalaan ymmärrettävänä asiana. Näin kyse on Jumalan hyvän tahdon toteutumisesta tavalla tai toisella. Tällainen kärsimyksen selitys eli niin sanottu teodikea oli historiallisen sielunhoidon taustalla Lutherista 1960-luvun terapeuttiseen käänteeseen asti. Kärsimys tulkittiin uskonnollisena asiana ja sitä hoidettiin uskonnollisin keinoin.

Teodikea eli kärsimykselle jonkinlaisen sen merkitystä tai tarkoitusta selittävän vastauksen antaminen on kuitenkin eettisesti kestämätön. Teodikea sivuuttaa kärsivän ihmisen kokemuksen ja tämän itse kärsimykselleen sisällyttämät selitykset. Lopulta teodikea sivuuttaa koko kärsivän ihmisen. Ainoa moraalisesti kestävä tapa suhtautua kärsimykseen on siis antiteodikea, teodikean hylkääminen. Kärsimys on mieletöntä eikä sen tarkoitusta voi kärsivän ihmisen puolesta selittää. Ihmisen itsensä on kuitenkin prosessoitava kokemustensa eksistentiaalista merkitystä, minkä myötä kärsimyksen kokemus voi muotoutua osaksi laajempaa elämän merkityksellisyyttä ja mielekkyyttä.

Sielunhoidon terapeuttisessa käänteessä on luovuttu teodikeasta. Auttamista ei määritä kärsimyksen selittäminen uskonnollisena asiana, vaan antiteodikea, kärsimyksen mielettömyyden tunnustaminen. Käänne antiteodikealaiseen kärsimystä koskevaan selitykseen on olennainen ja radikaali muutos kirkon tavoissa lievittää kärsimystä. Kirkon hengellisen työn tekijän kannalta nykyinen terapeuttinen sielunhoidon lähestymistapa edellyttää kahden tason sitoutumista. Yhtäältä sieluhoitaja on sitoutunut kirkon opetukseen ja sen edustamiin muun muassa kärsimystä koskeviin uskonnollisiin käsityksiin. Toisaalta sielunhoitajan on sitouduttava kärsimyksen mielettömyyden tunnustamiseen perustuvaan auttamisen tapaan.

Eletyn uskonnon periaatteiden mukaisesti kristityltä ei kuitenkaan voida edellyttää tiukkaa sitoutumista yhteisönsä uskonnolliseen opetukseen. Lähtökohtaisesti on riittävää, että kristitty ei ainakaan erikseen kiistä uskonnollisen yhteisönsä keskeistä opetusta - sielunhoidon kohdalla tarkoittaen sitä, että kirkon jäsen ei kiistäisi yleisen pappeuden opetuksen sanoittamaa evankeliumin luonnetta ja omaa rooliaan evankeliumin edistämisen suhteen. Norma- 
tiivisen antiteodikealaisen kärsimykseen suhtautumisen valossa ei itse asiassa tarvitse suhtautua ongelmana siihen, että kirkon jäsenet eivät sisällyttäisi moraaliseen toimintaansa uskonnollisia merkityksiä. Päinvastoin uskonnollisen tulkinnan puuttuminen voi mahdollistaa sen, että suhtautuu lähimmäisen hätään vakavasti pyrkimättä selittämään sitä pois.

Sielunhoito kristittyjen harjoittamana on jäänyt vähälle huomiolle niin kirkon piirissä kuin tutkimuksessakin. Sielunhoidon tarkasteleminen rakkautena toteutuvana kärsimyksen lievittämisenä avaa mahdollisuuden nähdä, miten sielunhoito voisi olla kristittyjen arkista toimintaa ja osa ihmisenä olemisen peruskysymyksiä. Sielunhoidon perinteisten latinankielisten nimitysten - cura animarum generalis ja cura animarum specialis, yleinen ja erityinen sielunhoito - rinnalle voisi vakiinnuttaa kristittyjen harjoittamaa sielunhoitoa tarkoittaman termin: cura animarum mundana, maallisessa elämässä tehtävä sielunhoito.

Lectio precursoria. Teologisessa tiedekunnassa, Helsingin yliopistossa 29.1.2021.

\section{Kirjallisuus}

Peltomäki, I. (2021). Kärsimys ja rakkaus:

Cura animarum mundana. Helsinki: Unigrafia. http://urn.fi/URN:ISBN:978-

951-51-6779-8 